\title{
Influence of Diets High and Low in Animal Fat on Bowel Habit, Gastrointestinal Transit Time, Fecal Microflora, Bile Acid, and Fat Excretion
}

\author{
J. H. Cummings and H. S. Wiggins, Medical Research Council Dunn Nutrition \\ Unit, Cambridge, England \\ D. J. A. Jenkins and Helen Houston, Medical Research Council Gastroenterology \\ Unit, Central Middlesex Hospital, London, England \\ T. JivraJ, B. S. Drasar, and M. J. Hill, Bacterial Metabolism Research Laboratory, \\ Colindale Hospital, London, England
}

A B S T R A C T Epidemiological observations and animal experiments suggest that large bowel cancer is related to several factors. Among them, high dietary intakes of animal fat, the presence in the colon of relatively high levels of bile acids, specific patterns of intestinal microflora, slow transit through the gut, and low stool weights. Under metabolic conditions we have observed the effect on these variables of diets containing 62 or $152 \mathrm{~g} /$ day of fat mainly of animal origin in six healthy young men over 4 -wk periods. No change attributable to the diet was observed in the subjects' bowel habit, fecal weight, mean transit time through the gut, or in the excretion of dry matter. Total fecal bile acid excretion was significantly higher on the high fat $\operatorname{diet}(320 \pm 120 \mathrm{mg} /$ day $)$ than on the low fat diet $(139.7$ $\pm 63 \mathrm{mg} / \mathrm{day}) t$ test $=7.78 P<0.001$ as also was the total fecal fatty acid excretion, $3.1 \pm 0.71$ and $1.14 \pm 0.35$ $\mathrm{g} /$ day, respectively $t$ test $=11.4 P<0.001)$. The fecal microflora including the nuclear dehydrogenating clostridia were unaltered by the dietary changes as was fecal $\beta$-glucuronidase activity. Dietary changes which increase animal fat intake clearly influence fecal bile acid excretion in a way that would favor the development of large bowel cancer if current theories prove to be true. Dietary fat however has no effect on overall colonic function so other components of the diet must be responsible for the observed associations of bowel cancer with slow transit and reduced fecal bulk.

Dr. Drasar's present address is London School of Hygiene and Tropical Medicine.

Received for publication 2 August 1977 and in revised form 30 November 1977.

\section{INTRODUCTION}

The high incidence of large bowel cancer found in "Western" or industrialized communities is associated with high dietary intakes of fat, animal protein, and low intakes of dietary fiber (1-5). The hypothesis relating low fiber consumption to large bowel cancer has aroused considerable interest, but at the present time adequate data on dietary fiber intake at the international level are not available to assess. The association of high animal protein intake with colonic cancer is clear but no satisfactory mechanism has been proposed to account for this apart from the association of high fat intakes found commonly in populations also consuming high animal protein intakes (6). For dietary fat, however, there is both evidence of an epidemiological link with large bowel cancer and of a possible causal mechanism.

Large bowel cancer is thought to be due to the presence of carcinogens in the bowel lumen. Bile acids may be carcinogenic, may act as co-carcinogens, or may be degraded by colonic microflora to carcinogens (7-8). When the stools of subjects from different countries with contrasting large bowel cancer rates are compared the high colon cancer rates are associated with higher fecal bile acid excretion and a greater preponderance of fecal anaerobic bacteria (9-11) including nuclear dehydrogenating (ndh) ${ }^{1}$ clostridia (12) although these bacteriological changes are not consistently found (13, 14). In a comparison of subjects with colon cancer and

${ }^{1}$ Abbreviations used in this paper: DF, dietary fiber; HFD, high fat diet; LFD, low fat diet; MTT, mean transit time; ndh, nuclear dehydrogenating. 
control patients with matched symptoms, $76 \%$ of the cancer patients had a combination of ndh clostridia in their stool and $>6 \mathrm{mg} / \mathrm{g}$ fecal solids of bile acids whereas only $9 \%$ of the control patients showed this (15).

If dietary fat and fecal bile acids are both causally related to large bowel cancer, a possible mechanism would be for dietary fat to increase fecal bile and acid excretion. Previous studies of the effect of dietary fat intake on bile acid excretion in man have looked mainly at the effect of different types of fat on fecal bile acids. It has been shown that diets high in polyunsaturates result in greater bile acid excretion in the stools than ones high in saturated fat $(16,17)$. Much less attention has been given to the role of different levels of fat intake of similar fatty acid composition. Early studies of this problem showed that fecal bile acid excretion was unaltered by increasing dietary intake of saturated fat, usually as butter or hydrogenated coconut fat (18-20). Recently, Hill (21) showed that four normal subjects on a hospital low fat diet decreased their fecal bile acid concentration when compared with their normal diet.

Because of the relationship between dietary fat and large bowel cancer we observed, in six normal people, the effect of diets high and low in animal fat on fecal bile acid output and also on bowel habit, mean transit time (MTT) through the gut, and the fecal microflora because these factors are relevant to the large bowel cancer hypothesis (22).

\section{METHODS}

\section{Subjects and study plan}

Six healthy male medical students aged 21-24 were each studied for $10 \mathrm{wk}$. During two consecutive 4 -wk periods they ate either a high fat or low fat diet in turn whereas during the first and last week of the study they maintained their normal diets. Throughout these two ad lib. weeks of diet the students weighed and recorded all food and drink taken. The design was such that three students ate the high fat diet first and three the low fat diet first. Volunteers lived in a student hostel on the grounds of the hospital and were expected to continue their normal activities and life-style throughout the study. No subject received any medication before or during the study and alcohol was not allowed. All remained healthy throughout.

\section{Diets (Tables I-III)}

The diets were prepared in the metabolic diet kitchen, with most of the food required for the study being purchased in bulk at the start. Three 1-day menus of similar composition were designed for each diet and were fed in rotation. Two complete samples, of each of the three individual days diet, were collected on two occasions during each part of the study and their fatty acid content analyzed. The overall composition of the diet was obtained from food table data (Table II).

Calculation of dietary intakes during the ad lib. weeks at the beginning and end of the study was done with the aid of the Medical Research Council dietary analysis com-
TABLE I

Daily Menus

\begin{tabular}{|c|c|c|c|c|c|}
\hline \multicolumn{6}{|l|}{ Low fat diet } \\
\hline & \multicolumn{2}{|l|}{ g/day } \\
\hline \multicolumn{4}{|c|}{$\begin{array}{l}\text { Orange juice (tinned, natural } \\
\text { unsweetened }\end{array}$} & \multicolumn{2}{|l|}{200} \\
\hline \multicolumn{4}{|l|}{ Cornflakes } & \multicolumn{2}{|l|}{50} \\
\hline \multicolumn{4}{|c|}{ Jam (raspberry) } & \multicolumn{2}{|l|}{25} \\
\hline \multicolumn{4}{|c|}{ Egg (medium size) } & \multicolumn{2}{|l|}{50} \\
\hline \multicolumn{4}{|l|}{ Sugar } & \multicolumn{2}{|l|}{100} \\
\hline \multicolumn{4}{|c|}{ Osborne biscuits } & \multicolumn{2}{|l|}{40} \\
\hline \multicolumn{4}{|c|}{ Bread-white sliced } & \multicolumn{2}{|l|}{180} \\
\hline \multicolumn{4}{|c|}{ Butter } & \multicolumn{2}{|l|}{35} \\
\hline \multicolumn{4}{|l|}{ Potato } & \multicolumn{2}{|l|}{150} \\
\hline \multicolumn{4}{|l|}{ Rice } & \multicolumn{2}{|l|}{150} \\
\hline \multicolumn{4}{|l|}{ Lettuce } & \multicolumn{2}{|l|}{20} \\
\hline \multicolumn{4}{|l|}{ Cucumber } & \multicolumn{2}{|l|}{20} \\
\hline \multicolumn{4}{|l|}{ Tomato } & \multicolumn{2}{|l|}{60} \\
\hline \multicolumn{4}{|l|}{ Yogurt (plain) } & \multicolumn{2}{|l|}{140} \\
\hline \multicolumn{4}{|l|}{ Skimmed milk } & \multicolumn{2}{|c|}{$568 \mathrm{ml}$} \\
\hline \multicolumn{2}{|l|}{ Day 1} & Day 2 & & Day 3 & \\
\hline & $g$ & & $g$ & & $g$ \\
\hline Plaice & 75 & Chicken & 75 & Beef & 75 \\
\hline Green beans & 100 & Mixed veg. & 50 & Tomato & 50 \\
\hline Apricots & 120 & Brussel & 50 & Broccoli & 50 \\
\hline (tinned) & & sprouts & & Peaches & 120 \\
\hline Lamb & 75 & Fruit salad & 120 & (tinned) & \\
\hline & & $\begin{array}{l}\text { (tinned) } \\
\text { Tuna fish }\end{array}$ & 75 & $\begin{array}{l}\text { Cottage } \\
\text { cheese }\end{array}$ & 75 \\
\hline
\end{tabular}

Modifications for high fat diet

Daily allowances

Cornflakes and rice-omitted

Double cream $-50 \mathrm{~g}$ added

Bread-reduced to $60 \mathrm{~g}$

Butter-increased to $70 \mathrm{~g}$

Potato-reduced to $50 \mathrm{~g}$

Whole milk replaced skimmed milk

\begin{tabular}{ccc}
\hline Day 1 & Day 2 & Day 3 \\
\hline $\begin{array}{c}\text { Cheddar cheese } \\
100 \mathrm{~g}\end{array}$ & Pork 100 g & Lamb 100 g \\
replaced lamb & replaced chicken & $\begin{array}{c}\text { replaced cottage } \\
\text { cheese }\end{array}$ \\
\hline
\end{tabular}

puter program, based on the food tables of McCance and Widdowson (25).

Dietary fat intake was $62 \mathrm{~g}$ /day on the low fat diet (LFD) and $152 \mathrm{~g} /$ day on the high fat diet (HFD). This change to HFD was brought about by increasing the butter intake from 35 to $70 \mathrm{~g} / \mathrm{day}$, substituting whole milk for skimmed milk, and adding $50 \mathrm{~g}$ of double cream. These changes accounted for $74 \mathrm{~g}(82 \%)$ of the increase, the rest coming from the substitutions of pork for chicken and cheddar cheese for cottage cheese. The additional fat in the diet was therefore derived entirely from animal sources. As a result of this, total cholesterol intake was altered from $466 \mathrm{mg}$ (LFD) to $732 \mathrm{mg}$ (HFD). To keep the overall caloric content of the diet constant, carbohydrates were reduced by $173 \mathrm{~g} /$ day in the high fat diet. This was achieved by cutting out $50 \mathrm{~g}$ of cornflakes, $150 \mathrm{~g}$ of rice, $120 \mathrm{~g}$ of white bread, and $100 \mathrm{~g}$ of potatoes. 


\section{Fecal collections}

Throughou the 10-wk period subjects collected their stools. Each stool was collected separately into a plastic bag fixed within a toilet bowl. The bag was then sealed, labeled, cooled to $-20^{\circ} \mathrm{C}$, weighed, and then stored. At the end of the study feces were pooled into 7-day collections allowed to thaw and homogenized while still cold, sufficient distilled water being added to ensure good mixing of the homogenate. Aliquots of homogenate were then stored at $-20^{\circ} \mathrm{C}$ before analysis.

\section{Markers}

On each day of the 8-wk period during which the diets were taken, the subjects took 15 radiopaque markers $(5 /$ meal). Two types of marker were used: (a) radiopaque bariumimpregnated polythene pellets (Portex Ltd. Hythe, Kent, England), sp gr 1.25 and an average weight $31 \mathrm{mg}$; $(b)$ radiopaque circles made by cutting $1.1-\mathrm{mm}$ sections off radiopaque tubing (Portex radiopaque tubing $R_{5}$ ) of $4.5 \mathrm{~mm}$ external diameter. These had a sp gr of 1.63 and an average weight of $16 \mathrm{mg}$. These two types of marker have previously been shown to behave similarly in the gut $(26)$ and were used interchangeably. Each marker was given for alternating 2-wk periods. This was done because if a marker recovery in the feces were to be incomplete it would still be possible to identify the 2 -wk period when the loss occurred. Where markers were being used simply to correct for variability in fecal output, small losses are not important but when they are also being used to measure MTT small differences are important because these losses produce a cumulative effect on the calculation of MTT. Marker output in the stool was measured by X-raying every stool passed. MTT, being the average time that a marker takes to pass through the gut, was calculated for each day of the study during which the markers were given, from a knowledge of the amount of marker ingested less the amount of marker excreted at any point in time. Full details of this method and calculation have been described (26).

\section{Bacteriological methods}

Preservation of specimens. From a freshly passed stool $0.5 \mathrm{~g}$ of feces was "biopsied" by Dr. Cummings out of the center of the sample with a modified sterile plastic syringe and immediately mixed with $4.5 \mathrm{ml}$ of $10 \%$ glycerol broth in a 6 -ml screw-top glass bottle with a sterile wooden spatula. The suspension was frozen by placing in a container of solid carbon dioxide and then stored at $-80^{\circ} \mathrm{C}$. This procedure which took 2-3 min and was usually completed within $15 \mathrm{~min}$ of defecation, ensures that losses of bacteria are minimized. The $10 \%$ glycerol protects bacteria from the effects of freez-

TABLE II

Composition of Diets per Day*

\begin{tabular}{lcc}
\hline & Low fat & High fat \\
\hline Calories & 2,684 & 2,852 \\
Fat, $g$ & 62 & 152 \\
Protein, $g$ & 99 & 94 \\
Carbohydrate, $g$ & 456 & 283 \\
Crude fiber, $g$ & 4.1 & 3.0 \\
Calcium, $m m o l$ & 33 & 37 \\
Cholesterol, $m g$ & 466 & 732 \\
\hline
\end{tabular}

* Calculated from food tables $(23,24)$.
TABLE III

Dietary Fatty Acids*

\begin{tabular}{lrr}
\hline & Low fat & High fat \\
\hline & & g/day \\
C12:0 & 1.1 & \\
C14:0 & 3.3 & 3.1 \\
C15:0 & 0.4 & 11.1 \\
C15 branched & 0.3 & 1.3 \\
C16:0 & 12.7 & 0.9 \\
C16:1 & 1.0 & 37.0 \\
C18:0 & 5.4 & 2.4 \\
C18:1 ISO & 2.6 & 14.1 \\
C18:1 & 14.3 & 5.6 \\
C18:2 + C18:3 & 4.9 & 30.1 \\
Others & 1.7 & 5.9 \\
Total & 47.7 & 5.4 \\
\end{tabular}

* Measured in two samples of each day's menu by gas-liquid chromatography as described in methods.

ing and in the frozen state the lethal influence of oxygen is minimized. No losses from frozen feces of nonsporing anaerobic bacteria have been detected (27).

Culture of specimens. Serial dilutions of the specimens were prepared and plates of media for the isolation of anaerobic organisms were seeded within an anaerobic chamber. A flexible polyvinyl chamber filled with a mixture of $10 \%$ hydrogen in nitrogen was used $(28,29)$.

10 -fold dilutions of the specimen were prepared in BrainHeart Infusion Broth (Oxoid Ltd., London) containing $\mathbf{0 . 0 5 \%}$ (wt/vol) cysteine hydrochloride and $0.03 \%$ sodium formaldehydesulfoxylate. The diluent was heated to $100^{\circ} \mathrm{C}$ before being introduced into the cabinet where it was dispensed and allowed to cool in the anaerobic environment and then used for the preparation of dilutions of the specimens. $0.1-\mathrm{ml}$ samples of appropriate dilutions were spread on the surface of the plates of the various selective and nonselective media used in previous studies (30). In addition to these media Brain-Heart agar (Oxoid Ltd.) containing $1 \%$ yeast extract (Oxoid Ltd.), $0.05 \%$ cysteine hydrochloride, and $0.03 \%$ sodium formaldehydesulfoxylate, enriched with $10 \%$ defibrinated horse blood (BHIA) were used for the isolation of nonsporing anaerobic bacteria and BHIA with $10 \%$ bile (Oxoid Ltd.) and $1,000 \mu \mathrm{g} / \mathrm{ml}$ of kanamycin sulfate to ensure the selection of Bacteroides fragilis.

To maintain the media in a reduced state, uninoculated plates were stored for 3 days in the anaerobic cabinet before use. Plates seeded within the cabinet, for the isolation of anaerobes, were packed into anaerobic jars and removed from the cabinet via the airlock. All anaerobic jars were evacuated and filled with a gas mixture containing $30 \% \mathrm{CO}_{2}$ and $70 \%$ $\mathrm{H}_{2}$. The atmosphere of the anaerobic jars was replaced twice. Cold "D" catalyst was used in the anaerobic jars (Englhard Industries, Cinderford, Gloucestershire, England). Plates for the isolation of facultative and aerobic bacteria were incubated aerobically. After incubation the colonies growing on the various media were counted. 10 strains of nonsporing anaerobic bacteria and 10 strains of clostridia were isolated from each specimen. The nonsporing anaerobes were further identified on the basis of criteria described (31). The volatile fatty acid end products of glucose metabolism were detected by direct gas chromatography of broth samples using the Perkin-Elmer F.40 automatic head space analyzer (Per- 
kin-Elmer UK Ltd., Beaconsfield, England). This type of chromatograph automatically samples and analyzes up to 30 samples. This technique for use with bacterial cultures has been described (12). Further tests were performed using a microfermentation system $(12,29)$. Indole tests were performed in this microsystem using indole-nitrate medium (Baltimore Biological Laboratories, Baltimore, Md.). The ability of the clostridia to dehydrogenate the steroid nucleus was tested using the improved method of Goddard et al. (32). The amount of $\beta$-glucuronidase in fecal specimens assayed by the method of Reddy and Wynder (10).

\section{Chemical methods}

Duplicate aliquots of feces from each week of the study were analyzed for dry matter, fatty acids, total bile acids, and calcium. Fatty acids in the diet and in stools were estimated by gas-liquid chromatography. An aliquot of homogenate of diet or stool was hydrolyzed as described by van de Kamer et al. (33) after $20 \mathrm{mg}$ of 2-methyl palmitic acid had been added (34). The fatty acids were extracted into toluene (35) which was evaporated and methyl esters of the residual acids formed with freshly prepared diazo methane. The methyl esters were analyzed with a Pye 104 gas-liquid chromatograph (Pye Instruments, Cambridge, England) using a 7-foot column with Apiezon-L stationary phase. The results are expressed as the total fatty acids of chain lengths 12-18 carbon atoms, which constitute $95 \%$ of the dietary fatty acids.

Fecal solids were measured by freeze drying an aliquot of homogenate to constant weight. Fecal calcium was measured in an acid extract of an ashed sample of homogenate equivalent to $5 \mathrm{~g}$ of the original stool.

Fecal steroids were extracted from freeze-dried feces using glacial acetic acid. The acid and neutral steroids were separated by the method of Evrard and Janssen (36). $\left[{ }^{14} \mathrm{C}\right] \mathrm{Cholic}$ acid was incorporated into the freeze-dried feces as an internal standard. The acid steroid fraction was dissolved in $3 \mathrm{ml}$ ethanol and treated with $5 \mathrm{mg}$ sodium borohydride for $1 \mathrm{~h}$; after careful acidification with hydrochloric acid the reduced acid steroids were extracted with ether and quantitated by the hydroxysteroid dehydrogenase method of Iwata and Yamasaki (37). Values were corrected for recovery of internal standard which was $80-85 \%$. Coefficient of variation in duplicate aliquots of a freeze-dried sample for the whole method was $9 \%$.

The results presented are based on the 4th wk of each diet period unless otherwise specified. Fecal output of fatty acids, bile acids, calcium and fecal weight have been corrected for marker output. Statistical comparison of the data from the two diet periods has been by the paired $t$ test. All data are given \pm 1 SD unless otherwise specified.

\section{RESULTS}

Marker recovery. The six subjects took 15 markers daily for 8 wk except that one dose of five markers was omitted by one subject, giving a total marker intake of 5,035 . Of these only six were not recovered, an average recovery of $99.88 \%$. Three subjects showed completed marker recovery whereas in the other three: 1,2 , and 3 markers were not recovered.

Bowel habit and MTT. All subjects had a normal bowel habit at the start of the study. Their average frequency of defecation during the lst wk of the study when an ad lib. diet was taken was 5/wk (range three
TABLE IV

Fecal Weight, Dry Matter and MTT during Final Week of Each Diet Period

\begin{tabular}{llll}
\hline & LFD & \multicolumn{1}{c}{ HFD } & $t$ test* \\
\hline Fecal weight, g/day & $101.3 \pm 27.7$ & $93.8 \pm 27.0$ & 1.03 \\
Fecal dry matter, & & & \\
$\quad$ g/100 g stool & $27.8 \pm 4.2$ & $28.4 \pm 6.2$ & 0.51 \\
Fecal dry matter, g/day & $27.3 \pm 4.5$ & $25.5 \pm 4.3$ & 1.48 \\
MTT, $h$ & $58.2 \pm 16.7$ & $57.3 \pm 23.3$ & 0.17
\end{tabular}

Data is mean \pm 1 SD.

* None of the $t$ test values indicate significance at $P>0.2$.

to nine) and their average fecal weight $120 \pm 41 \mathrm{~g} /$ day. No significant differences were observed in fecal weight, fecal frequency, fecal excretion of solids, and MTT due to the changes in the metabolic diets (Table IV).

Bile acids and fatty acids. Total fecal bile acid excretion on the low fat diet was $139.7 \pm 63 \mathrm{mg} /$ day. On the high fat diet this increased significantly to $320 \pm 120 \mathrm{mg} /$ day $(\mathrm{t}=7.78, P<0.001)$. Individual responses to the different diets may be seen in the Fig. 1. All subjects showed an increase in fecal bile acid output when changed to the high fat diet. On the low fat diet fecal bile acid excretion fell throughout the 4-wk period, this trend reaching statistical significance between wk 2 and 4 where fecal bile acid excretion was $175 \pm 76 \mathrm{mg} /$ day in wk 2 and $140 \pm 63 \mathrm{mg} / \mathrm{day}$ in wk $4(\mathrm{t}=3.29, P<0.025)$. No such trend was noted on the high fat diet (Table V). Fecal bile acid excretion during the $2 \mathrm{wk}$ the subjects were taking an ad lib. diet was $212 \pm 41$ and $207 \pm 76 \mathrm{mg} /$ day which was midway between the levels seen during the two controlled diet periods.

Fecal fatty acid excretion also increased on the high fat diet. Total excretion on the low fat diet was 1.14 $\pm 0.35 \mathrm{~g} /$ day rising to $3.1 \pm 0.71 \mathrm{~g} /$ day $(\mathrm{t}=11.4 ; P<0.001)$ on the high fat diet. The average increase in fatty acid output was $1.96 \pm 0.42 \mathrm{~g} / \mathrm{day}$ of which C16:0 and C18:0 accounted for $76.0 \% \pm 10.32$ (Table VI).

Fecal calcium. Fecal calcium excretion was not significantly changed by the alteration in diet. On the low fat diet it was $26.4 \pm 3.0$ and $26.9 \pm 4.7 \mathrm{mmol} /$ day on the high fat diet.

Fecal microflora. Alteration of the amount of fat in the diet produced no demonstrable change in the relative numbers of bacteria groups counted from the feces (Table VII). Because the output of feces remained the same on both diets so did the total number of bacteria excreted daily.

Nonsporing anaerobic bacteria were the predominant fecal organisms isolated. 981 strains were isolated and identified during the study. The organism most frequently isolated was Bacteroides fragilis Subsp. 

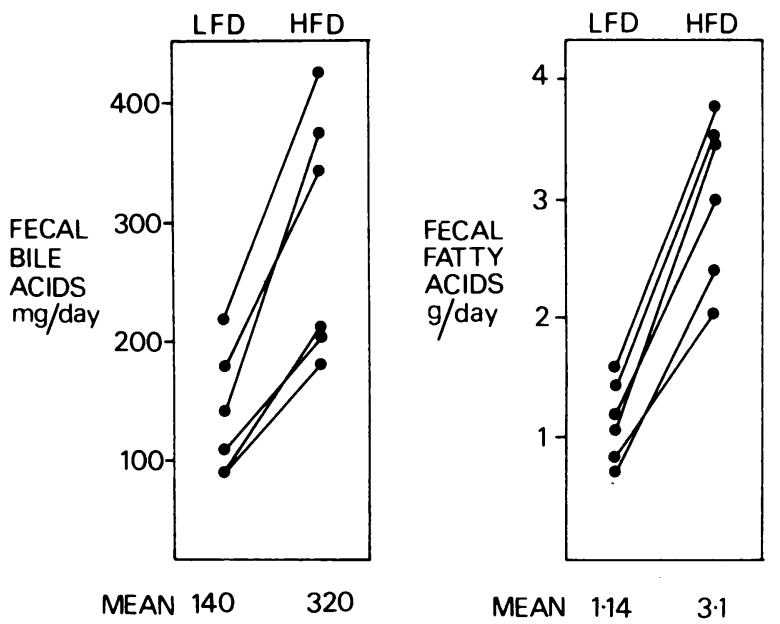

FIGURE 1 Fecal bile acid output (milligram per day) and fatty acid output (gram per day) corrected for marker output in each subject during the 4 th wk of each diet period.

thetaiotaomicron. Details of the relative frequency of the groups of nonsporing anaerobes are presented in Table VIII. It should be remembered that as 10 isolates/specimen were identified only organisms comprising at least $10 \%$ of the flora will be consistently identified. Bacteria of the $B$. fragilis group dominated the flora of all subjects throughout the study. The relative proportions of the various species fluctuated during the $10 \mathrm{wk}$. In general $B$. fragilis subsp. vulgatus and subsp. distasonis were displaced by subsp. thetaiotaomicron other subspecies varying randomly.

Fecal $\beta$-glucuronidase. Fecal $\beta$-glucuronidase activity was assayed on six occasions in each subject during the study, twice during the ad lib. diet and twice during the 3rd or 4th wk of each metabolic diet period. Mean values were: ad lib. diet $117 \pm 63 \mathrm{mmol}$ $\beta$-glucuronide hydrolyzed/h per g feces; LFD $119 \pm 39$ $\mathrm{mmol} / \mathrm{h}$ per g; HFD $108 \pm 46 \mathrm{mmol} / \mathrm{h}$ per $\mathrm{g}$. Considerable variation was seen between the two samples on each diet (coefficient of variation 39\%). Individual differences between the HFD and LFD were not significant: $\mathrm{t}=0.73 P>0.4$.

Clostridia able to dehydrogenate the steroid nucleus $n d h$. Clostridia able to perform this reaction were isolated from all the subjects during the LFD although in subject $\mathrm{H}$ only a single isolation was made after 15 days of the diet. In subjects $\mathrm{Y}, \mathrm{W}$, and $\mathrm{Wi}$ isolates were obtained during all dietary periods (Table VII). Overall the concentration and frequency of isolation of these organisms was not altered by the diets.

\section{DISCUSSION}

This study shows that dietary changes which increase animal fat intake lead to an increase in fecal bile acid and fatty acid output but do not cause changes in fecal
TABLE V

Fecal Bile Acid Excretion

\begin{tabular}{cccc}
\hline Week & Diet & Fat intake & Fecal bile acids \\
\hline & & g/day & $m g / d a y$ \\
First* $^{*}$ & Ad lib. & $112 \pm 26$ & $212 \pm 41$ \\
$1 \ddagger$ & Low fat & 62 & $192 \pm 65$ \\
2 & Low fat & 62 & $175 \pm 76$ \\
3 & Low fat & 62 & $161 \pm 75$ \\
4 & Low fat & 62 & $140 \pm 63$ \\
$1 \ddagger$ & High fat & 152 & $304 \pm 127$ \\
2 & High fat & 152 & $353 \pm 155$ \\
3 & High fat & 152 & $338 \pm 122$ \\
4 & High fat & 152 & $320 \pm 120$ \\
Last* & Ad lib. & $87 \pm 29$ & $207 \pm 76$ \\
\hline
\end{tabular}

Data are shown $\pm 1 \mathrm{SD}$.

* Not corrected for marker output.

$\$$ Three subjects not corrected for marker output.

microflora, bowel habit, or in overall transit through the gut.

Dietary changes. These particular dietary changes were made because epidemiologically high animal rather than vegetable fat intakes are associated with large bowel cancer (3). Increasing animal fat intake by this means while maintaining caloric equivalence for the two diets resulted in cholesterol intakes also rising from 466 to $732 \mathrm{mg}$ /day and to changes in dietary fiber intake. Although it is possible that these changes are responsible for the observed effect of the diet in evidence cited below, it does suggest that the changes in fat intake are more important.

Caloric balance was achieved by reducing the intake of refined carbohydrate foods (cornflakes, white bread, etc.) on the HFD to minimize changes in fiber intake. Table II shows crude fiber intake (crude fiber = resi-

TABLE VI

Fecal Fatty Acid Composition*

\begin{tabular}{lll}
\hline & \multicolumn{1}{c}{ LFD } & HFD \\
\hline C14:0 & $0.2 \pm 0.1$ & $0.9 \pm 0.3$ \\
C15:0 & $0.2 \pm 0.05$ & $0.3 \pm 0.1$ \\
C15 branched & $0.2 \pm 0.1$ & $0.2 \pm 0.1$ \\
C16:0 & $2.5 \pm 0.9$ & $8.4 \pm 1.8$ \\
C16:1 & $0.1 \pm 0.05$ & $0.1 \pm 0.05$ \\
C18:0 & $2.2 \pm 1.0$ & $6.6 \pm 1.6$ \\
C18:1 ISO & $0.5 \pm 0.2$ & $1.5 \pm 0.8$ \\
C18:1 & $0.7 \pm 0.1$ & $1.4 \pm 0.3$ \\
C18:2 +3 & $0.9 \pm 0.4$ & $1.1 \pm 0.6$ \\
Others $\ddagger$ & $0.5 \pm 0.1$ & $1.1 \pm 0.6$ \\
Total & $8.0 \pm 2.45$ & $21.7 \pm 5.0$ \\
\hline
\end{tabular}

* Gram per week \pm 1 SD.

$\ddagger$ C12 and unidentified fatty acids. 
TABLE VII

Mean (Range) $\log _{10}$ Viable Count Selected Bacteria from Feces of Six Subjects Consuming Their Normal Diet and after at Least 2 Wk on the Experimental Diets

\begin{tabular}{|c|c|c|c|c|c|c|c|c|c|}
\hline & \multicolumn{3}{|c|}{ Subject $Y$} & \multicolumn{3}{|c|}{ Subject $\mathbf{T}$} & \multicolumn{3}{|c|}{ Subject $\mathbf{H}$} \\
\hline & AL & LFD & HFD & $\mathrm{AL}$ & LFD & HFD & AL & LFD & HFD \\
\hline $\begin{array}{r}\text { Enterobac- } \\
\text { teriaceae }\end{array}$ & $\begin{array}{c}7.2 \\
6.4-8.6\end{array}$ & $\begin{array}{c}6.2 \\
5.0-7.3\end{array}$ & $\begin{array}{c}6.5 \\
6.2-7.1\end{array}$ & 6.8 & $\begin{array}{c}7.2 \\
6.6-7.9\end{array}$ & $\begin{array}{c}7.4 \\
6.9-8.1\end{array}$ & $\begin{array}{c}7.6 \\
6.8-8.2\end{array}$ & $\begin{array}{c}5.6 \\
4.5-6.2\end{array}$ & $\begin{array}{c}7.0 \\
6.1-8.0\end{array}$ \\
\hline $\begin{array}{l}\text { Fecal } \\
\quad \text { Enterococci }\end{array}$ & $\begin{array}{c}6.5 \\
6.0-8.4\end{array}$ & $\begin{array}{c}5.5 \\
4.3-7.6\end{array}$ & $\begin{array}{c}5.9 \\
4.5-7.1\end{array}$ & 6.4 & $\begin{array}{c}7.1 \\
6.1-8.5\end{array}$ & $\begin{array}{c}6.7 \\
6.3-7.3\end{array}$ & $\begin{array}{c}6.3 \\
5.7-6.8\end{array}$ & $\begin{array}{c}5.5 \\
4.9-6.2\end{array}$ & $\begin{array}{c}5.9 \\
5.7-6.2\end{array}$ \\
\hline $\begin{array}{l}\text { Viridans Strep- } \\
\quad \text { tococci }\end{array}$ & $\begin{array}{c}8.0 \\
6.3-9.5\end{array}$ & $\begin{array}{c}6.0 \\
4.6-7.6\end{array}$ & $\begin{array}{c}6.1 \\
4.7-7.4\end{array}$ & 6.5 & $\begin{array}{c}7.3 \\
6.5-8.5\end{array}$ & $\begin{array}{c}7.1 \\
6.8-7.3\end{array}$ & $\begin{array}{c}6.7 \\
5.5-7.7\end{array}$ & $\begin{array}{c}6.2 \\
5.8-7.1\end{array}$ & $\begin{array}{c}6.2 \\
5.5-6.8\end{array}$ \\
\hline Lactobacilli & $\begin{array}{c}6.0 \\
5.1-6.9\end{array}$ & $\begin{array}{c}6.1 \\
5.4-7.7\end{array}$ & $\begin{array}{c}6.1 \\
5.9-6.4\end{array}$ & 5.5 & $\begin{array}{c}6.1 \\
5.6-6.5\end{array}$ & $\begin{array}{c}5.4 \\
5.2-5.8\end{array}$ & $\begin{array}{c}2.9 \\
2.5-3.4\end{array}$ & $\begin{array}{c}4.2 \\
3.0-5.2\end{array}$ & $\begin{array}{c}4.8 \\
\mathrm{D}-6.0\end{array}$ \\
\hline Bacteroides & $\begin{array}{c}10.5 \\
10.4-10.7\end{array}$ & $\begin{array}{c}10.5 \\
10.3-10.7\end{array}$ & $\begin{array}{c}10.8 \\
10.5-11.5\end{array}$ & 10.5 & $\begin{array}{c}10.4 \\
9.9-10.9\end{array}$ & $\begin{array}{c}10.6 \\
10.5-10.7\end{array}$ & $\begin{array}{c}10.7 \\
10.5-11.1\end{array}$ & $\begin{array}{c}10.8 \\
10.5-11.1\end{array}$ & $\begin{array}{c}10.9 \\
10.8-11.0\end{array}$ \\
\hline Clostridia & $\begin{array}{c}5.5 \\
5.0-6.1\end{array}$ & $\begin{array}{c}5.4 \\
3.5-6.3\end{array}$ & $\begin{array}{c}4.0 \\
3.5-4.3\end{array}$ & 5.0 & $\begin{array}{c}4.1 \\
3.2-4.6\end{array}$ & $\begin{array}{c}6.0 \\
5.7-6.3\end{array}$ & $\begin{array}{c}3.9 \\
2.5-4.8\end{array}$ & $\begin{array}{c}3.2 \\
D-4.5\end{array}$ & $\begin{array}{c}4.1 \\
\mathrm{D}-6.5\end{array}$ \\
\hline ndh clostridia & $\begin{array}{l}3.6 \\
D-5.0\end{array}$ & $\begin{array}{c}4.7 \\
\mathrm{D}-6.0\end{array}$ & $\begin{array}{c}3.7 \\
\mathrm{D}-4.3\end{array}$ & D & $\begin{array}{c}3.4 \\
\mathrm{D}-5.5\end{array}$ & D & D & D & D \\
\hline $\begin{array}{c}\text { Number of } \\
\text { samples }\end{array}$ & 4 & 4 & 3 & 1 & 4 & 3 & 3 & 3 & 4 \\
\hline
\end{tabular}

D, <2.5; AL, Ad lib. diet; LFD, Low fat diet; HFD, High fat diet.

due of foodstuff left after sequential treatment with solvent, dilute aqueous acid, and dilute alkali [38]) at $4.1 \mathrm{~g} /$ day LFD and $3.0 \mathrm{~g}$ /day HFD. However crude fiber is now recognized to be a considerable underestimate of total dietary fiber in a foodstuff (39) (dietary fiber $[D F]=$ plant cell wall structures and plant polysaccharides not digested in the human upper gastrointestinal tract [40]). We therefore calculated DF in-

\section{TABLE VIII}

The Relative Frequency Expressed as a Percentage of Total Isolates of Bacterial Groups in each of Six Subjects during Fat Diet Study

\begin{tabular}{lcccccc}
\hline & \multicolumn{7}{c}{ Subject } \\
\cline { 2 - 7 } & $\mathrm{Y}$ & $\mathrm{T}$ & $\mathrm{H}$ & $\mathrm{W}$ & $\mathrm{M}$ & $\mathrm{Wi}$ \\
\hline B. fragilis group & 73.5 & 73.5 & 78.0 & 75.0 & 61.0 & 79.0 \\
Subsp.-distasonis & 17 & 10 & 10 & 18 & 15 & 10.5 \\
Subsp.-fragilis & 14.5 & 8 & 6 & 18 & 3 & 22 \\
Subsp.-ovatus & 0 & 0.5 & 0 & 1 & 2 & 0 \\
Subsp.-thetaiotaomicron & 22 & 15 & 41 & 9 & 24 & 8 \\
Subsp.-vulgatus & 8 & 6 & 13 & 2 & 9 & 28 \\
Subsp.-other & 12 & 34 & 8 & 27 & 8 & 10.5 \\
Fusobacterium & 21 & 17 & 17 & 21 & 34 & 19 \\
Bifido bacterium & 0 & 4 & 4 & 1 & 3 & 2 \\
Eubacterium & 3 & 4 & 0 & 1 & 1 & 0 \\
Propionobacterium & 0.5 & 0.5 & 0 & 1 & 0 & 0 \\
Anaerobic cocci & 0.5 & 0 & 0 & 1 & 1 & 0 \\
\hline
\end{tabular}

takes in each diet (41). This gives a DF value in our LFD of 22.2 and $10.6 \mathrm{~g} /$ day in the HFD. This difference in DF intake may however be exaggerated as the DF content of processed foodstuffs such as cornflakes may be too high due to the presence of substances formed during heating which interfere in the method. ${ }^{2}$ Nevertheless it is clear that measurement of crude fiber values are inadequate even on a comparative basis as an indicator of total DF intakes.

These changes are unlikely to be responsible for the differences in fecal bile acid and fatty acid output observed as fiber intakes fell and the bile acid outputs increased. Fiber however has well-documented effects on bowel habit and the fall in intake may have masked an effect on bowel habit due to increased fat intake. This possibility is also unlikely because it is the pentose fraction of the noncellulosic polysaccharides in fiber that are most closely associated with fecal bulking (42). Intakes of this fiber fraction were similar on the two diets, $2.1 \mathrm{~g} /$ day LFD and $1.9 \mathrm{~g} /$ day HFD. The differences in dietary fiber intake was largely due to cellulose and to hexose containing polysaccharide intakes.

Fecal bile acids. Fecal bile acid excretion in these subjects was within the normal range expected for

\footnotetext{
2 Southgate, D. A. T. Personal communication.
} 
TABLE VII (Continued)

\begin{tabular}{|c|c|c|c|c|c|c|c|c|}
\hline \multicolumn{3}{|c|}{ Subject $\mathrm{W}$} & \multicolumn{3}{|c|}{ Subject M } & \multicolumn{3}{|c|}{ Subject $W_{i}$} \\
\hline $\mathrm{AL}$ & LFD & HFD & AL & LFD & HFD & AL & LFD & HFD \\
\hline $\begin{array}{c}7.9 \\
7.5-8.8\end{array}$ & $\begin{array}{c}8.1 \\
7.5-9.3\end{array}$ & $\begin{array}{c}7.6 \\
7.2-8.1\end{array}$ & $\begin{array}{c}7.2 \\
7.0-7.4\end{array}$ & $\begin{array}{c}5.6 \\
4.8-6.7\end{array}$ & $\begin{array}{c}8.3 \\
8.2-8.5\end{array}$ & $\begin{array}{c}5.8 \\
5.4-6.1\end{array}$ & $\begin{array}{c}5.6 \\
5.5-5.7\end{array}$ & $\begin{array}{c}5.6 \\
5.3-5.9\end{array}$ \\
\hline $\begin{array}{c}6.5 \\
5.5-8.3\end{array}$ & $\begin{array}{c}6.4 \\
6.1-7.2\end{array}$ & $\begin{array}{c}6.2 \\
5.5-6.6\end{array}$ & $\begin{array}{c}6.1 \\
5.7-6.5\end{array}$ & $\begin{array}{c}6.2 \\
5.5-6.8\end{array}$ & $\begin{array}{c}7.6 \\
7.6-7.7\end{array}$ & $\begin{array}{c}6.3 \\
5.4-7.9\end{array}$ & $\begin{array}{c}4.8 \\
4.6-5.0\end{array}$ & $\begin{array}{c}5.2 \\
4.5-5.9\end{array}$ \\
\hline $\begin{array}{c}8.3 \\
6.3-9.5\end{array}$ & $\begin{array}{c}7.5 \\
6.6-8.8\end{array}$ & $\begin{array}{c}6.9 \\
6.7-7.2\end{array}$ & $\begin{array}{c}6.9 \\
6.7-7.3\end{array}$ & $\begin{array}{c}6.4 \\
5.5-6.7\end{array}$ & $\begin{array}{c}7.9 \\
7.8-8.1\end{array}$ & $\begin{array}{c}6.6 \\
5.5-8.0\end{array}$ & $\begin{array}{c}6.9 \\
5.6-8.2\end{array}$ & $\begin{array}{c}6.2 \\
5.1-7.3\end{array}$ \\
\hline $\begin{array}{c}5.3 \\
5.2-5.5\end{array}$ & $\begin{array}{c}6.0 \\
4.4-7.0\end{array}$ & $\begin{array}{c}3.9 \\
3.4-4.7\end{array}$ & & $\begin{array}{c}2.6 \\
D-2.8\end{array}$ & $\begin{array}{c}5.7 \\
4.6-7.0\end{array}$ & $\begin{array}{c}6.5 \\
6.3-6.7\end{array}$ & $\begin{array}{c}3.5 \\
D-5.7\end{array}$ & $\begin{array}{c}3.2 \\
3.2-3.3\end{array}$ \\
\hline $\begin{array}{c}10.5 \\
10.2-10.7\end{array}$ & $\begin{array}{c}10.7 \\
10.6-10.9\end{array}$ & $\begin{array}{c}10.5 \\
10.3-10.7\end{array}$ & $\begin{array}{c}10.5 \\
10.5-10.5\end{array}$ & $\begin{array}{c}10.5 \\
10.5-10.5\end{array}$ & $\begin{array}{c}10.5 \\
10.5-10.5\end{array}$ & $\begin{array}{c}10.5 \\
10.4-10.6\end{array}$ & $\begin{array}{c}10.6 \\
10.5-10.7\end{array}$ & $\begin{array}{c}10.4 \\
10.3-10.5\end{array}$ \\
\hline $\begin{array}{c}6.3 \\
6.0-6.7\end{array}$ & $\begin{array}{c}5.1 \\
4.7-5.4\end{array}$ & $\begin{array}{c}6.1 \\
6.0-6.2\end{array}$ & $\begin{array}{c}5.8 \\
5.5-6.2\end{array}$ & $\begin{array}{c}6.5 \\
6.3-6.6\end{array}$ & $\begin{array}{c}6.4 \\
6.3-6.5\end{array}$ & $\begin{array}{c}5.8 \\
5.1-7.3\end{array}$ & $\begin{array}{c}4.8 \\
4.5-5.2\end{array}$ & $\begin{array}{c}6.2 \\
6.2-6.3\end{array}$ \\
\hline $\begin{array}{c}3.8 \\
D-5.9\end{array}$ & $\begin{array}{c}3.2 \\
\mathrm{D}-4.9\end{array}$ & $\begin{array}{c}4.6 \\
D-5.9\end{array}$ & $\begin{array}{c}4.2 \\
\mathrm{D}-5.9\end{array}$ & $\begin{array}{c}3.9 \\
D-6.3\end{array}$ & D & $\begin{array}{c}3.4 \\
D-5.1\end{array}$ & $\begin{array}{c}4.5 \\
4.1-4.9\end{array}$ & $\begin{array}{c}4.3 \\
\mathrm{D}-6.1\end{array}$ \\
\hline 3 & 4 & 3 & 2 & 3 & 2 & 3 & 2 & 2 \\
\hline
\end{tabular}

healthy young men although in 7 of the 24 wk of fecal collection on the low fat diet bile acid outputs were below $100 \mathrm{mg} /$ day. It is clear from this study however that dietary fat intake is a major determinant of fecal bile acid output and such low values might be expected on low fat intakes. The close relationship between fat intake and fecal bile acid excretion is further supported by the data from the weeks when the students were taking an ad lib. diet. Despite the relatively imprecise nature of data from ad lib. diet periods fat intakes (wk 1, $112 \pm 29 \mathrm{~g} /$ day; wk $10,87 \pm 29 \mathrm{~g} /$ day) were midway between the intakes on the metabolic diets and fecal bile acid excretion (wk 1, 212 $\pm 41 \mathrm{mg} /$ day; wk 10, $207 \pm 76 \mathrm{mg} /$ day) likewise midway between the output on these diets. When diets containing different levels of fat intake of similar fatty acid composition are fed fecal bile acid, excretion appears to be closely related to fat intake.

Bile acids are derived from cholesterol and dietary cholesterol intakes also increased along with fat intake. Ideally we should have preferred to keep the cholesterol intake constant while increasing animal fat intake but this is difficult to achieve with normal foods without changing the type of fatty acid composition of the diet which is known to affect bile acid output. Quintao et al. (43) increased cholesterol intakes in eight patients by between 542 and $4,058 \mathrm{mg} /$ day while holding fat intakes constant and were unable to show any effect on fecal bile acid output in any subject. Similar observations were made by Wilson and Lindsey (44). These suggest that dietary cholesterol is not a major determinant of fecal bile acid excretion.

Dietary fat is known to affect fecal bile acid excretion although it is the type of fat that is thought to be important. Increasing polyunsaturated fat intakes increases fecal bile acid output $(16,17,45,46)$. This effect of polyunsaturates is important in explaining the relationship between high polyunsaturate diets and lowered serum cholesterol. Because of the possible link between fecal bile acid outputs and large bowel cancer it might be worth reconsidering the widely offered advice for people to eat polyunsaturates in an attempt to maintain a low serum cholesterol level. An overall lowering of fat intake would seem more appropriate.

Attempts have been made in the past to relate the amount in addition to the type of dietary fat to fecal bile acids but with consistently negative results (16, 18-20). Moore et al. (16) failed to show an increase in fecal bile acid output when dietary fat was increased although in their study the increase was only $42 \mathrm{~g} /$ day on top of an already high fat intake of $145 \mathrm{~g} /$ day. Similarly, in a long-term study of South African white and Bantu prisoners, Antonis and Bersohn (18) weré unable to show a change in fecal bile acid output when butter was added to a LFD but did show an increase when 
sunflower-seed oil was used. In addition Gordon et al. (19) who also studied the Bantu failed to alter fecal bile acid output when $75 \mathrm{~g}$ dehydrogenated coconut fat was added to the LFD. These latter two studies were done at a time when the methodology of fecal bile acid estimation was relatively imprecise which might explain their variance with our present findings.

The way in which these dietary changes alter fecal bile acid excretion cannot be deduced from this study. Redinger et al. (47) noted that in Rhesus monkeys, dietary supplements of both saturated and polyunsaturated fats led to increased bile flow, bile salt synthesis, and an increased pool size. Lewis (48) however showed in three patients, with T-tube drainage after biliary surgery, that hydrogenated coconut fat did not increase cholic acid output in bile although sunflower-seed oil did. Such changes may be related not only to the degree of unsaturation but also to different fatty acid chain lengths.

Fecal fat. The relationship of fecal bile acid output to dietary fat intake may be partly explained by changes in fecal fat output. Weber et al. $(49,50)$ have shown in children with malabsorption that bile acid excretion is related to fecal fat excretion.

Fecal fat output increased significantly in our subjects along with fecal bile acid output (Fig. 1). With the development of careful metabolic balance techniques over the past two decades a much clearer relationship between dietary fat intake and fecal fat output has become recognized (51-53), even in normal subjects. We have confirmed in this study that fecal fat output increases when dietary fat intake increases. The increase in fecal fatty acids in our subjects was largely accounted for by C18:0 and C16:0 in the feces (Table VI). In the diet however, C18:1 intake also increased in addition to the other two fatty acids but this increase was not reflected in the stools. This is probably due to the ability of many strains of fecal microflora to metabolize oleic acid $(54,55)$. How this increase in fecal fat might influence the change in fecal bile acid output is not clear. Long chain fatty acids are said to inhibit bile acid reabsorption in the terminal ileum (56) but Weber et al. (50) have suggested that fecal triglycerides are more important than total fecal fat output in determining bile acid excretion in children with malabsorption. Increased fat intake however might mean simply a small increase in fat not absorbed in the small bowel on the basis that a constant (although high) proportion of dietary fat is absorbed. This may in turn alter bile acid absorption. Alternatively the bile acid pool size may increase leading to increased fecal excretion if a constant proportion is lost.

Fecal weight and MTT. Neither fecal weight nor MTT of marker through the gut were altered by these dietary changes. Values for both were within the nor- mal range we have found for medical students living on ad lib. diets $(26,57)$. It has been shown that both bile acids $(58,59)$ and fatty acids $(60)$ inhibit salt and water absorption in the human gut and thereby may contribute to diarrhea in certain malabsorptive states such as that seen in ileal resection patients $(60,61)$. Changes in fecal fatty acid and bile acid output are however much greater in such patients than those we observed in our students. Our study shows that over quite a wide range of dietary fat intake of animal origin fecal weight and MTT remain unaffected. These findings are of importance in the light of suggestions that large bowel diseases such as cancer and diverticular disease are due to diets producing a low fecal bulk and slow MTT. Dietary fat of this type seems to be neutral in these respects unlike dietary fiber that has a pronounced fecal bulking effect and shortens MTT (62).

Fecal microflora. No effect of diet on the bacterial groups studied was demonstrated during the course of this investigation. This confirms the results of our previous studies on wheat fiber and other dietary supplements $(63,64)$. In the present study an increase in ndh clostridia and a decrease in Eubacteria species on the high fat diet might have been expected on the basis of the theory linking fat consumption with large bowel cancer. No such change was apparent. Week by week changes in the relative proportion of subspecies of $B$. fragilis occurred but could not be related to diet. These were similar to changes observed by Holdeman et al. (65). Fecal $\beta$-glucuronidase activity also did not change but this was not surprising in view of the magnitude of the differences in the flora. Reddy et al. (66) showed a greatly reduced $\beta$-glucuronidase activity in the stools when subjects changed from a normal American to a no-meat diet.

The role of ndh clostridia in the etiology of colon cancer remains unclear. In previous studies the carriage of these bacteria seemed to be associated with increased cancer risk $(9,12,15)$ but recently both our own studies $(14,67)$ and those of Finegold $(13,68)$ have not confirmed this. The present study suggests that these microorganisms are in the short-term unaffected by alterations in the fat intake.

The major microbiological problem associated with studying the influence of factors controlling the flora is the number of bacterial isolates to be examined. Apparently the ability of bacteria to metabolize the various substrates entering the colon determines the flora. Study of alterations in the rates of metabolism of these substrates by fecal suspensions might prove to be a more rapid and sensitive method for detecting changes. This approach proved successful in a study of the metabolism of the food additive cyclamate (69). A similar approach was used by Hoskins and 
Boulding (70) in their study demonstrating the importance of blood group antigens in the control of some components of the flora.

Fecal bile acids and large bowel cancer. The epidemiological evidence relating large bowel cancer to high animal fat intakes is quite strong. The hypothesis that links these observations through an effect on bile acid metabolism is supported by the finding of lower fecal bile acid concentrations and a smaller proportion of bile acid metabolites in the feces of subjects from low cancer risk areas (9). In addition, patients with large bowel cancer may be largely distinguished from controls by their higher fecal bile acid concentrations (15). From our data it is clear that an increase in dietary fat intake leads to a significant increase in fecal bile acid output. The precise role which fecal bile acids play in the genesis of human large bowel has yet to be established, but in rats bile acids enhance tumor production induced by locally applied carcinogens in the large bowel (71). Similarly, in rats HFD increase fecal bile acid output and increase the susceptibility of the rats to dimethylhydrazine-induced tumors of the colon $(72,73)$. Together these factors suggest that serious consideration ought to be given to the hypothesis that dietary fat is important in the etiology of large bowel cancer. Such a hypothesis does not exclude the possibility that dietary fiber may also have a role to play in this disease, in fact the association of large bowel cancer with low fecal weight and slow intestinal transit suggests that dietary fat alone is unlikely to be the sole factor. Wheat fiber while increasing fecal bile acid output also produces major changes in fecal bulk so that overall large bowel contents are diluted (57). Fiber may therefore be a protective factor against cancer whereas fat through its effect on bile acid metabolism could be important in its initiation. The role of protein has yet to be established.

\section{ACKNOWLEDGMENTS}

The authors wish to express their thanks to the medical students who took part in the study without whom it would not have been possible. Also to Will Branch, Ranjit Choolun, and Kathy (Johnson) Alderton for their technical help.

Doctors Hill, Jenkins, and Drasar were in receipt of a grant from the Cancer Research Campaign.

\section{REFERENCES}

1. Armstrong, B., and R. Doll. 1975. Environmental factors and cancer incidence and mortality in different countries, with special reference to dietary practices. Int. J. Cancer. 15: 617-631.

2. Burkitt, D. P. 1971. Epidemiology of cancer of the colon and rectum. Cancer (Phila.). 28: 3-13.

3. Drasar, B. S., and D. Irving. 1973. Environmental factors and cancer of the colon and breast. Br. J. Cancer. 27: $167-172$.
4. Wynder, E. L., and T. Shigematsu. 1967. Environmental factors in cancer of the colon and rectum. Cancer (Phila.). 20: 1520-1561.

5. Gregor, O., R. Toman, and F. Prusova. 1969. Gastrointestinal cancer and nutrition. Gut. 10: 1031-1034.

6. Wynder, E. L. 1975. The epidemiology of large bowel cancer. Cancer Res. 35: 3388-3394.

7. Hill, M. J. 1975. The etiology of colon cancer. CRC. Crit. Rev. Toxicol. October 1975. 31-82.

8. Wynder, E. L., and B. S. Reddy. 1973. Studies of large bowel cancer: human leads to experimental application. J. Natl. Cancer Inst. 50: 1099-1106.

9. Hill, M. J., J. S. Crowther, B. S. Drasar, G. Hawkesworth, J. Aries, and R. E. O. Williams. 1971. Bacteria and aetiology of cancer of large bowel. Lancet. I: $95-100$.

10. Reddy, B. S., and E. L. Wynder. 1973. Large bowel carcinogenesis: faecal constituents of populations with diverse incidence rates of colon cancer. J. Natl. Canc. Inst. 50: 1437-1442.

11. Hill, M. J., and B. S. Drasar. 1974. Bacteria and the aetiology of cancer of the intestine. In Anaerobic bacteria: role in disease. A. Balows, R. M. Behan, V. R. Dowell, and L. B. Gaze, editors. Thomas Springfield, Illinois. 119-133.

12. Drasar, B. S., P. Goddard, S. Heaton, S. Peach, and B. West. 1976. Clostridia isolated from faeces. J. Med. Microbiol. 9: 63-71.

13. Finegold, S. M., H. R. Attebery, and V. L. Sutter. 1974. Effect of diet on human fecal flora: comparison of Japanese and American diets. Am. J. Clin. Nutr. 27: 1456- 1469 .

14. I.A.R.C. Intestinal microecology group. 1977. Dietary fibre, transit-time, faecal bacteria, steroids and colon cancer in two Scandinavian populations. Lancet. II: $207-211$.

15. Hill, M. J., B. S. Drasar, R. E. O. Williams, T. W. Meade, A. G. Cox, J. E. P. Simpson, and B. C. Morson. 1975. Faecal bile acids, clostridia and the etiology of cancer of the large bowel. A case comparison study. Lancet. I: 535-538.

16. Moore, R. B., J. T. Anderson, H. L. Taylor, A. Keys, and I. D. Frantz. 1968. Effect of dietary fat on the faecal excretion of cholesterol and its degradation products in man. J. Clin. Invest. 47: 1517-1534.

17. Connor, W. E., D. T. Witiak, D. B. Stone, and M. L. Armstrong. 1969. Cholesterol balance and fecal neutral steroids and bile acid excretion in normal men fed dietary fats of different fatty acid composition. J. Clin. Invest. 48: $1363-1375$.

18. Antonis, A., and I. Bersohn. 1962. The influence of diet on fecal lipids in South African white and Bantu prisoners. Am. J. Clin. Nutr. 11: 142-155.

19. Gordon, H., B. Lewis, L. Eales, and J. F. Brock. 1957. Dietary fat and cholesterol metabolism. Faecal elimination of bile acids and other lipids. Lancet. II: 12991306.

20. Haust, H. L., and J. M. R. Beveridge. 1958. Effect of varying type and quantity of dietary fat on the faecal excretion of bile acids in humans subsisting on formula diets. Arch. Biochem. Biophys. 78: 367-375.

21. Hill, M. J. 1971. The effect of some factors on the faecal concentration of acid steroids, neutral steroids and urobilins. J. Pathol. 104: 239-245.

22. Burkitt, D. P., A. R. P. Walker, and N. S. Painter. 1972. Effect of dietary fibre on stools and transit times, 
and its role in the causation of disease. Lancet. II: 1408-1412.

23. McCance, R. A., and E. M. Widdowson. 1960. The Composition of Foods. Medical Research Council Special Report Series No. 297. HMSO London.

24. Watt, B. K., and A. L. Merrill. 1963. Composition of foods. Agriculture Handbook No. 8. U. S. Dept. of Agriculture, Washington, D. C.

25. Brereton, P., M. J. R. Healey, and M. Pitteway. 1973. A simple computerised system for dietary calculation. Nutrition. 27: 200-205.

26. Cummings, J. H., D. J. A. Jenkins, and H. S. Wiggins. 1976. Measurement of the mean transit time of dietary residue through the human gut. Gut. 17: 210-218.

27. Crowther, J. S. 1971. Transport and storage of faeces for bacteriological examination. J. Appl. Bacteriol. 34: 477483.

28. Aranki, A., S. A. Syed, E. R. Kenney, and R. Freter. 1969. Isolation of anaerobic bacteria from human gingiva and mouse cecum by means of a simplified glove box procedure. Appl. Microbiol. 17: 568-576.

29. Drasar, B. S. 1974. Isolation and identification of nonsporing anaerobes. In Infection with non-sporing anaerobic bacteria. I. Philips and M. Sussman, editors. Churchill-Livingstone, Edinburgh. 20-35.

30. Drasar, B. S. 1967. Cultivation of anaerobic intestinal bacteria. J. Pathol. Bacteriol. 94: 417-427.

31. Peach, S., F. Fernandez, K. Johnson, and B. S. Drasar. 1974. The non-sporing anaerobic bacteria in human faeces. J. Med. Microbiol. 7: 200-221.

32. Goddard, P., F. Fernandez, B. West, M. J. Hill, and P. Barnes. The nucleur dehydrogenation of steroids by intestinal bacteria. J. Med. Microbiol. 8: 429-435.

33. van de Kamer, J. H., H. ten Bokkel Huinink, and H. A. Weyers. 1949. Rapid method for the determination of fat in faeces. J. Biol. Chem. 177: 347-355.

34. Napier, E. A. 1963. 2-methylalkanoic acids as internal standards in gas-liquid chromatographic assay of fatty acids. Anal. Chem. 35: 1294-1295.

35. Jover, A., and R. S. Gordon. 1962. Procedure for quantitative analysis of faeces with special reference to faecal fatty acids. J. Lab. Clin. Med. 59: 878-884.

36. Evrard, E., and S. Janssen. 1968. Gas-liquid chromatographic determination of human faecal bile acids. J. Lipid. Res. 9: 226-236.

37. Iwata, T., and K. Yamasaki. 1964. Enzymatic determination and TLC of bile acids in blood. J. Biochem. (Tokyo). 56: 424-431.

38. Horwitz, W. 1970. Crude Fibre in Official methods of analysis of the Association of Official Analytical Chemists, U. S. A. W. Horwitz editors. AOAC, Washington, D. C., 11th edition. 129.

39. Van Soest, P. J., and R. W. McQueen. 1973. The chemistry and estimation of fibre. Proc. Nutr. Soc. 32: $123-130$.

40. Cummings, J. H. 1976. What is Fibre? In Fibre in human nutrition. G. A. Spiller and Amen, editors. Plenum Publishing Corporation. New York. 1-30.

41. Southgate, D. A. T., B. Bailey, E. Collinson, and A. F. Walker. 1976. A guide to calculating intakes of dietary fibre. J. Human Nutr. 30: 303-313.

42. Cummings, J. H., D. A. T. Southgate, W. Branch, Helen Houston, D. J. A. Jenkins, and W. P. T. James. 1978. The colonic response to dietary fibre from carrot, cabbage, apple, bran and guar gum. Lancet. 1: 5-8.

43. Quintao, E., S. M. Grundy, and E. H. Ahrens. 1971.
Effects of dietary cholesterol on the regulation of total body cholesterol in man. J. Lipid Res. 12: 23-247.

44. Wilson, J. D., and C. A. Lindsey. 1965. Studies on the influence of dietary cholesterol on cholesterol metabolism in the isotopic steady state in man. J. Clin. Invest. 44: 1805-1814.

45. Sodhi, H. S., P. D. S. Wood, G. Schlierf, and L. W. Kinsell. 1967. Plasma, bile and fecal steroids in relation to diet. Metab. Clin. Exp. 16: 334-344.

46. Avigan, J., and D. Steinberg. 1965. Sterol and bile acid excretion in man and the effects of dietary fat. $J$. Clin. Invest. 44: 1845-1856.

47. Redinger, R. N., A. H. Hermann, and D. M. Small. Primate biliary physiology. X. Effects of diet and fasting on biliary lipid secretion and relative composition and bile salt metabolism in the rhesus monkey. Gastroenterology. 64: 610-621.

48. Lewis, B. 1958. Effect of certain dietary oils on bile acid secretion and serum cholesterol. Lancet. I: 10901092.

49. Weber, A. M., C. C. Roy, C. L. Morin, and R. Lasalle. 1973. Malabsorption of bile acids in children with cystic fibrosis. N. Engl. J. Med. 289: 1001-1005.

50. Weber, A. M., C. C. Roy, L. Chartrand, G. Lepage, O. L. Dufour, C. L. Morin, and R. Lasalle. 1976. Relationship between bile acid malabsorption and pancreatic insufficiency in cystic fibrosis. Gut. 17: 295-299.

51. Walker, B. E., J. Kelleher, T. Davies, C. L. Smith, and M. S. Losowsky. 1973. Influence of dietary fat on faecal fat. Gastroenterology. 64: 233-239.

52. Kasper, H. 1970. Fecal fat excretion, diarrhoea and subjective complaints with highly dosed oral fat intake. Digestion. 3: 321-331.

53. Wollaeger, E. E. 1973. Role of the ileum in fat absorption. Mayo Clin. Proc. 48: 836-843.

54. Pearson, J. R., H. S. Wiggins, and B. S. Drasar. 1974. Conversion of long-chain unsaturated fatty acids to hydroxy acids by human intestinal bacteria. J. Med. Microbiol. 7: 265-275.

55. Thomas, P. J. 1972. Identification of some enteric bacteria which convert oleic acid to hydroxy stearic acid in vitro. Gastroenterology. 62: 430-435.

56. Ammon, H. V., and S. F. Phillips. 1974. Inhibition of ileal water absorption by intraluminal fatty acids. $J$. Clin. Invest. 53: 205-210.

57. Cummings, J. H., and H. S. Wiggins. 1975. Transit through the gut measured by analysis of a single stool. Gut. 17: 219-223.

58. Mekhjian, H. S., S. F. Philips, and A. F. Hofmann. 1971. Colonic secretion of water and electrolytes induced by bile acids: perfusion studies in man. J. Clin. Invest. 50: 1569-1577.

59. Wingate, D. L., E. Krag, H. S. Mekhjian, and S. F. Philips. 1973. Relationship between ion and water movement in the human jejunum, ileum and colon during perfusion with bile acids. Clin. Sci. Mol. Med. 45: 593-606.

60. Ammon, H. V., and S. F. Philips. 1973. Inhibition of colonic water and electrolyte absorption by fatty acids in man. Gastroenterology. 65: 744-749.

61. Hofmann, A. F., and J. R. Poley. 1972. Role of bile acid malabsorption in pathogenesis of diarrhoea and steatorrhoea in patients with ileal resection. Gastroenterology. 62: 918-934.

62. Cummings, J. H., M. J. Hill, D. J. A. Jenkins, J. R. Pearson, and H. S. Wiggins. 1976. Changes in faecal com- 
position and colonic function due to cereal fibre. Am. J. Clin. Nutr. 29: 1468-1473.

63. Drasar, B. S., D. J. A. Jenkins, and J. H. Cummings, 1976. The influence of a diet rich in wheat fibre on the human faecal flora. J. Med. Microbiol. 9: 423-431.

64. Drasar, B. S., and D. J. A. Jenkins. 1976. Bacteria, diet and large bowel cancer. Am. J. Clin. Nutr. 29: 1410-1416.

65. Holdeman, L. V., I. J. Good, and W. E. C. Moore. 1976. Human fecal flora: variation in bacterial composition within individuals and a possible effect of emotional stress. Appl. and Environ. Microbiol. 31: 359-375.

66. Reddy, B. S., J. S. Weisburger, and E. L. Wynder. 1974. Fecal bacterial $\beta$-glucuronidase: control by diet Science (Wash. D. C.). 183: 416-417.

67. Crowther, J. S., B. S. Drasar, M. J. Hill, R. MacLennan, D. Maguin, S. Peach, and C. H. Teoh-Chan. 1976. Faecal steroids and bacteria and large bowel cancer in Hong-Kong by socio-economic groups. Br. J. Cancer. 34: $191-198$.
68. Finegold, S. M., D. J. Flora, H. R. Attebery, and V. L. Sutter. 1975. Fecal bacteriology of colonic polyp patients and control patients. Cancer Res. 35: 3407-3417.

69. Drasar, B. S., A. G. Renwick, and R. T. Williams. 1972. The role of the gut flora in the metabolism of cyclamate. Biochem. J. 129: 881-890.

70. Hoskins, L. C., and E. T. Boulding. 1976. Degradation of blood group antigens in human colon ecosystems. I. In vitro production of $\mathrm{ABH}$ blood group-degrading enzymes by enteric bacteria. J. Clin. Invest. 57: 63-73.

71. Reddy, B. S., T. Narisawa, R. Maronpot, J. H. Weisberger and E. L. Wynder. 1975. Animal models for the study of dietary factors and cancer of the large bowel. Cancer Res. 35: 3421-3426.

72. Reddy, B. S., J. H. Weisberger, and E. L. Wynder. 1974. Effects of dietary fat level and dimethylhydrazine on faecal acid and neutral sterol excretion and colon carcinogenesis in rats. J. Natl. Cancer Inst. 52: 507-511.

73. Rogers, A. E., and P. M. Newberne. 1975. Dietary effects on chemical carcinogenesis in animal models for colon and liver tumours. Cancer Res. 35: 3427-3431. 